\title{
Effects of dietary sources of vegetable fats on performance of dairy ewes and conjugated linoleic acid (CLA) in milk
}

\author{
T. Castro ${ }^{\mathrm{a}, *}$, T. Manso $^{\mathrm{b}}$, V. Jimeno $^{\mathrm{c}}$, M. Del Alamo $^{\mathrm{b}}$, A.R. Mantecón $^{\mathrm{d}}$ \\ a Departamento de Producción Animal, Facultad de Veterinaria, Universidad Complutense de Madrid, 28040 Madrid, Spain \\ b Area de Producción Animal, Escuela Técnica Superior de Ingenierias Agrarias, Universidad de Valladolid, 34004 Palencia, Spain \\ ' Departamento de Producción Animal, Universidad Politécnica de Madrid, 28040 Madrid, Spain \\ d Estación Agrícola Experimental, CSIC Apartado 788, 24080 León, Spain
}

A R T I C L E I N F O

Keywords:

Vegetable fats

Milk performance

Milk CLA

Dairy ewe

\begin{abstract}
A B S T R A C T
Two experiments were carried out to study the effects of supplementing the ration of lactating ewes with vegetable fats (sunflower oil, SO or hydrogenated palm oil, HPO; HIDROPALM $^{\circledR}$ ) on diet digestibility, milk yield and milk composition, and on the concentration of the conjugated linoleic acid (CLA) C18:2 cis-9 trans-11 and C18:1 trans-11 (vaccenic acid, VA) and other main fatty acids in milk fat. Treatments involved a control diet, without added oil, and 2 diets supplemented with either $12 \mathrm{~g} / \mathrm{kg}$ SO or $12 \mathrm{~g} / \mathrm{kg}$ HPO on a dry matter (DM) basis. In the first experiment, 6 non-pregnant, non-lactating Lacaune ewes were used following a $3 \times 3$ replicated Latin Square design. Addition of vegetable fat supplement to the diet increased digestibility of DM, organic matter (OM) and crude protein (CP), but did not affect that of the ether extract (EE), neutral detergent fibre (NDF) or acid detergent fibre (ADF). In the second experiment, 60 Lacaune dairy ewes mid-way through lactation ( $120 \pm 12$ days in milk, $0.98 \pm 0.03 \mathrm{~kg} /$ day average milk yield) were divided into three equalsized groups each of which was assigned to one of the three experimental diets for 4 weeks. Compared with the control treatment, supplementation with HPO increased milk yield and energy-corrected milk. But neither vegetable fat supplement modified percentages of fat and protein in milk. Supplementation with HPO increased C14:1, C16:1 and C16:0 content and reduced $\mathrm{C} 18: 0$ and $\mathrm{C} 18: 1 \mathrm{cis}-9$ content in milk fat. Supplementation with SO increased the VA content in milk fat by $36 \%$ and that of cis- 9 trans-11 CLA by $29 \%$ in comparison with the control diet. Supplementation with HPO led to milk fat with $15 \%$ more cis-9 trans-11 CLA than control milk. In conclusion, adding a moderate dose of HPO or SO to the diets increased CLA concentration in milk fat. Nevertheless, supplementation with SO was more effective than HPO in increasing CLA concentration in milk fat and reducing the atherogenicity index, improving milk quality from the human health standpoint.
\end{abstract}

Abbreviations: ADF, acid detergent fibre; CLA, conjugated linoleic acid; $\mathrm{CP}$, crude protein; DM, dry matter; EE, ether extract; FAMEs, fatty acid methyl esters; NDF, neutral detergent fibre; OM, organic matter; SO, sunflower oil; HPO, hydrogenated palm oil; LCFA, long-chain fatty acids; PUFA, polyunsaturated fatty acids; TMR, total mixed ration; VA, vaccenic acid.

* Corresponding author. Tel.: +34 913943784; fax: +34913943768.

E-mail address: tcastro@vet.ucm.es (T. Castro).

\section{Introduction}

Lipids, in addition to supplying dietary energy to dairy ruminants, can modify the fat composition of their milk (Chilliard et al., 2000; Schmidely and Sauvant, 2001). This is of great importance, given the beneficial effects of some long-chain fatty acids (LCFA) on human health. The term conjugated linoleic acid (CLA) refers to a mixture of geometric and positional isomers of octadecadienoic acid with conjugated double bonds. The cis-9 trans- 11 isomer, the 
most abundant CLA, is considered to have anticarcinogenic properties (Ip et al., 1999), while trans-10, cis-12 CLA is capable of lowering body fat and increasing lean body mass (Park et al., 1999). trans-10, cis-12 CLA also decreases the concentration of fat in cow milk (Peterson et al., 2002) and of ewe milk (Lock et al., 2006).

Dietary polyunsaturated fatty acids (PUFA), which undergo incomplete ruminal biohydrogenation, are one source of cis-9 trans-11 CLA in milk fat. The principal source, however, is endogenous synthesis in the mammary gland from vaccenic acid (VA, $C_{18: 1}$ trans-11), an intermediate that also escapes complete biohydrogenation in the rumen (Griinari et al., 2000).

In recent years there have been numerous studies on increasing CLA content in the milk of dairy cattle using a dietary supplement of vegetable oils rich in C18:2 (Bell et al., 2006; Huang et al., 2008). Few studies on CLA milk content, however, have been carried out in dairy ewes given PUFA-rich oils, such as sunflower oil (SO) or soybean oil. The few studies report an increase in VA and cis-9 trans-11 CLA content in milk fat (Zhang et al., 2006; Bouattour et al., 2006).

In intensive dairy sheep farming systems, hydrogenated palm oil or calcium soaps of palm oil, are usually used as dietary supplements. However, these oils have little C18:2, a precursor of cis-9 trans-11 CLA and VA in the rumen.

The aim of this study was to investigate the effects of supplementing dairy ewe diets with hydrogenated palm oil (HPO), used as an alternative to calcium soaps, or SO, rich in $\mathrm{C} 18: 2$, on milk yield and composition, and on milk fatty acids profile including CLA content.

\section{Materials and methods}

Two experiments were conducted simultaneously to study the effects of SO and HPO supplements on the apparent digestibility of the diets, and on lactational performance and fatty acid profile of milk fat. Animal care procedures followed in this study were approved by the Committee of Animal Experimentation of the Complutense University of Madrid.

\subsection{Animals, treatments, and experimental procedures}

\subsubsection{Experiment 1}

Six dry (non-pregnant, non-lactating) Lacaune ewes $(71.4 \pm 2.29 \mathrm{~kg}$ body weight) were used in a replicated $3 \times 3$ Latin Square design with 21 days periods. Ewes were housed in individual cages $(0.90 \mathrm{~m} \times 1.45 \mathrm{~m})$ that permitted total collection of feces separately from feed residues and urine. Separate collection of feces and urine was made possible using a metal screen which was placed under the metabolism cages at an angle of approximately $45^{\circ}$. The fecal pellets dropped were collected into plastic bags and placed inside plastic containers.

Treatments consisted of a control diet, without added oil, and 2 diets supplemented with either $12 \mathrm{~g} / \mathrm{kg}$ SO or $12 \mathrm{~g} / \mathrm{kg}$ HPO (HIDROPALM ${ }^{\circledR}$, NOREL, SA, Madrid, Spain) on a dry matter (DM) basis. Experimental rations were formulated to be isoenergetic and isoproteic and were supplied as total mixed ration (TMR), with a forage:concentrate ratio of $60: 40$ twice a day (09:00 and 17:00 h). Ingredients and chemical composition of experimental rations, and the fatty acid profile of fat supplements, are presented in Tables 1 and 2, respectively. Animals had free access to fresh water.

For 6 consecutive days, following a 15-day adaptation period, the quantity of feed consumed and that of feces from each animal were registered. Samples of feed and orts were taken daily, pooled for each animal and dried at $60^{\circ} \mathrm{C}$ to constant weight. A representative sample $(10 \%)$ of the feces of each ewe was taken daily and kept frozen at $-20^{\circ} \mathrm{C}$ until subsequent analysis.
Table 1

Ingredients and chemical composition of diets.

\begin{tabular}{lccc}
\hline Composition & \multicolumn{2}{l}{ Treatment $^{\mathrm{a}}$} & \\
\cline { 2 - 4 } & Control & SO & HPO \\
\hline Ingredients (g/kg) & & & \\
Oat hay & 353 & 258 & 258 \\
Alfalfa hay & 240 & 367 & 367 \\
Barley meal & 141 & 141 & 141 \\
Corn meal & 85 & 84 & 84 \\
Whole cotton seed & 58.4 & 34.8 & 34.8 \\
Soybean meal (44\% CP) & 112 & 94 & 94 \\
Sunflower oil & 0 & 10.6 & 0 \\
Hydrogenated palm oil & 0 & 0 & 10.6 \\
Mineral-vitamin mix & 10.6 & 10.6 & 10.6 \\
Chemical composition (g/kg DM) & & & \\
CP & 153 & 154 & 143 \\
Ether extract & 28.3 & 35.1 & 36.0 \\
NDF & 453 & 424 & 467 \\
ADF & 241 & 233 & 263 \\
UFLc (mcal/kg) & 0.75 & 0.75 & 0.75 \\
\hline
\end{tabular}

a Treatments: SO, sunflower oil and HPO, hydrogenated palm oil.

${ }^{b}$ Mineral-vitamin mix (NUTEMIX ${ }^{\mathbb{E}}$, NUTEGA, Madrid, Spain) provided (per kg of premix): Ca, $186 \mathrm{~g} ; \mathrm{P}, 50 \mathrm{~g} ; \mathrm{Mg}, 61 \mathrm{~g}$; Na, $39 \mathrm{~g} ; \mathrm{Zn}, 3 \mathrm{~g} ; \mathrm{Mn}, 2 \mathrm{~g} ; \mathrm{S}$, $2 \mathrm{~g}$; I, $0.1 \mathrm{~g} ; \mathrm{Fe}, 0.26 \mathrm{~g}$; Co, $0.04 \mathrm{~g}$; Se, $0.03 \mathrm{~g}$ vitamin A, 400,000 IU; vitamin $\mathrm{E}, 1 \mathrm{~g}$; vitamin D, 80,000 IU and BTH (butylated hydroxytoluene), $0.2 \mathrm{~g}$.

c UFL: feed unit for milk production. Estimated from INRA (2007).

\subsubsection{Experiment 2}

Sixty multiparous Lacaune dairy ewes were divided into three groups of 20 each, homogenous for milk yield (average milk production $=0.98 \pm 0.030 \mathrm{~kg}$ per head per day), days of lactation (average days in milk $=120 \pm 12$ ), and body weight (mean live weight $=74.3 \pm 0.93 \mathrm{~kg}$ ). Animals were assigned randomly to one of three experimental diets and group-fed by treatment for ad libitum intake (about 105\% of expected intake, $2.4 \mathrm{~kg}$ per head per day) twice a day (9:00 and 17:00 h). The animals pens were of the same size with similar stall design, flooring and water accessibility. Experimental diets were described in Experiment 1 (Table 1) and supplied as TMR. Ewes had free access to water. Milking took place once a day (11:00 h). After a 2-week period of adaptation to the experimental diets, 4-week experimental period was initiated in which milk yield was weekly recorded and sampled for subsequent laboratory analysis. A portion of milk $(50 \mathrm{~mL})$ from each ewe was stored at $4{ }^{\circ} \mathrm{C}$ and used to determine fat and protein content, while another aliquot was stored at $-20^{\circ} \mathrm{C}$ for later fatty acid analysis.

\subsection{Analytical methods}

Contents of DM, ash, crude protein (CP), and ether extract (EE), were determined for each sample of feed, orts and feces, by AOAC (1999) official methods. Neutral detergent fibre (NDF) and acid detergent fibre (ADF) analyses were carried out as described by Van Soest et al. (1991), using the ANKOM ${ }^{200 / 220}$ Fiber Analyser (ANKOM Technology Corp., Fairport, NY). NDF analysis was performed with sodium sulphite and a heat stable amylase and expressed with residual ash. ADF was also expressed with residual ash.

Table 2

Fatty acid composition of the fat supplements.

\begin{tabular}{lcl}
\hline Fatty acids $(\mathrm{g} / 100 \mathrm{~g}$ of total fatty acids) & \multicolumn{2}{l}{ Fat supplements } \\
\cline { 2 - 3 } & SO & HPO \\
\hline $\mathrm{C} 14: 0$ & 0.07 & 1.23 \\
$\mathrm{C} 16: 0$ & 5.96 & 62.50 \\
$\mathrm{C} 18: 0$ & 3.98 & 25.67 \\
$\mathrm{C} 18: 1$ & 28.82 & 9.82 \\
$\mathrm{C} 18: 2$ & 60.53 & 0.07 \\
$\mathrm{C} 18: 3$ & 0.07 & Not detected
\end{tabular}

a SO: sunflower oil; HPO: hydrogenated palm oil. 
Samples of the fat supplements used (HPO and SO) were analyzed by gas chromatography to determine their fatty acid profiles. For esterification of fatty acids, $0.2 \mathrm{~g}$ of fat was weighted and diluted in $4 \mathrm{~mL}$ hexane, the solution was transferred into a centrifuge tube and $200 \mu \mathrm{L} \mathrm{KOH}$ was added. After mixing, tubes were incubated for $30 \mathrm{~min}$ and later centrifuged for $30 \mathrm{~s}$ at $2000 \mathrm{rpm}$. The upper organic layer was transferred into the glass vial for GC analysis. GC analysis employed a Agilent Technologies $6890 \mathrm{~N}$ instrument with FID detector and software turbochrom 4. For separation a $30 \mathrm{~m} \times 0.32 \mathrm{~mm}$ (i.d.) fused capillary column (Omegawax 320, $0.25 \mu \mathrm{m}$ film thickness, Supelco, Bellefonte, PA) was used. Column temperature program: $190^{\circ} \mathrm{C}$ maintained $2 \mathrm{~min}$, slope $5^{\circ} \mathrm{C} / \mathrm{min}$ until $230^{\circ} \mathrm{C}$ maintained $3 \mathrm{~min}$. Injector and FID temperatures were $260^{\circ} \mathrm{C}$, helium was used as the carrier gas under head pressure of 11 psi. Split injection (100:1) was performed.

Protein and fat contents of milk were determined using a Milkoscan4000 (Foss Electric, Hillerød, Denmark).

Separation of the fat for fatty acid analysis was performed by centrifuging $20 \mathrm{~mL}$ of milk at $12,000 \times \mathrm{g}$ for $20 \mathrm{~min}$. Fatty acid methyl esters (FAMEs) of milk were obtained by alkaline transesterification, following the method described by Wolff and Fabien (1989). Afterward, FAMEs were extracted with $1 \mathrm{~mL}$ of hexane. Hexane was evaporated to dryness under a nitrogen stream, and FAMEs were subsequently dissolved in $1 \mathrm{~mL}$ of hexane. FAMEs were analyzed by gas chromatography using a HewlettPackard HP-6890A gas chromatograph, equipped with an on-column injector and a flame ionization detector, using a polyethyleneglycol capillary column (Supelcowax-10, Supelco, Bellefonte, PA) $(60 \mathrm{~m} \times 0.32 \mathrm{~mm}$ i.d. $\times 0.25 \mu \mathrm{m}$ film thickness). Gas chromatograph oven program temperature was as follows: initial temperature of $180^{\circ} \mathrm{C}, 5^{\circ} \mathrm{C} / \mathrm{min}$ to $200^{\circ} \mathrm{C}$; $40 \mathrm{~min}$ at this temperature and thereafter $5^{\circ} \mathrm{C} / \mathrm{min}$ to $250^{\circ} \mathrm{C}$, and then kept for an additional $21 \mathrm{~min}$. Injector and detector temperatures were $250^{\circ} \mathrm{C}$. Carrier gas was nitrogen at a flow rate of $0.8 \mathrm{~mL} / \mathrm{min}$. C13:0 (Sigma-Aldrich, St.Louis, MO, USA) was added to each sample as an internal standard before methylation. Individual FAME peaks were identified by comparison of their retention times with those of standards (Sigma, St. Louis, MO)

\subsection{Statistical analyses}

Data from the digestibility study were analyzed as a replicated $3 \times 3$ Latin Square using the General Linear Models procedure of SAS (SAS Inst. Inc., Cary, NC). The model included effects of diet, period and ewe. Orthogonal contrast (1, control vs. SO and HPO; 2, SO vs. HPO) was used to compare treatment means.

Data for milk yield and milk composition, as well as for fatty acids profile in milk fat were analyzed as repeated measures using the PROC MIXED procedure of SAS (SAS Inst. Inc., Cary, NC). The diet was used as main effect and week of sampling was the repeated measure. Each sheep was considered as 1 experimental unit. The lowest Bayesian information criterion was used to choose the matrix of error structure. Least squares means were reported, and significance was declared at $P<0.05$.

\section{Results}

\subsection{Apparent digestibility}

As shown in Table 3 , addition of vegetable fat to the diet increased apparent digestibility of OM $(P=0.03)(0.665$

\section{Table 3}

Apparent digestibility of dietary DM and selected nutrients in nonlactating ewes fed diets supplemented with vegetable fats.

\begin{tabular}{llllllll}
\hline & \multicolumn{2}{l}{ Treatment $^{\mathrm{a}}$} & & \multirow{2}{*}{ S.E.M. } & \multicolumn{2}{c}{ Contrast, $^{\mathrm{b}} P$} \\
\cline { 2 - 3 } & Control & SO & HPO & & & 1 & 2 \\
\hline DM & 0.647 & 0.681 & 0.672 & 0.0106 & 0.06 & 0.55 \\
OM & 0.665 & 0.699 & 0.693 & 0.0096 & 0.03 & 0.68 \\
CP & 0.693 & 0.741 & 0.727 & 0.0157 & 0.07 & 0.55 \\
Ether extract & 0.708 & 0.725 & 0.688 & 0.0289 & 0.97 & 0.39 \\
NDF & 0.511 & 0.526 & 0.546 & 0.0156 & 0.23 & 0.40 \\
ADF & 0.453 & 0.468 & 0.490 & 0.0174 & 0.27 & 0.39 \\
\hline
\end{tabular}

a Treatments: SO, sunflower oil and HPO, hydrogenated palm oil.

b Contrast: 1, control vs. SO and HPO; 2, SO vs. HPO.
Table 4

Milk yield and milk composition of ewes fed diets supplemented with vegetable fats (data are least squares means).

\begin{tabular}{|c|c|c|c|c|}
\hline & \multicolumn{3}{|c|}{ Treatment $^{a}$} & \multirow[t]{2}{*}{ S.E.M. ${ }^{b}$} \\
\hline & Control & SO & $\mathrm{HPO}$ & \\
\hline Milk yield (g/day) & $762 b$ & $870 \mathrm{ab}$ & $934 a$ & 50.05 \\
\hline $\operatorname{ECM}^{\mathrm{c}}$ (g/day) & $942 b$ & $1020 \mathrm{ab}$ & $1151 \mathrm{a}$ & 58.98 \\
\hline \multicolumn{5}{|l|}{ Milk fat } \\
\hline $\mathrm{g} / \mathrm{kg}$ & 97.6 & 92.9 & 97.3 & 3.61 \\
\hline g/day & $74 \mathrm{~b}$ & $80 a b$ & $91 \mathrm{a}$ & 5.070 \\
\hline \multicolumn{5}{|l|}{ Milk protein } \\
\hline $\mathrm{g} / \mathrm{kg}$ & 75.2 & 71.7 & 74.9 & 2.05 \\
\hline g/day & $58 \mathrm{~b}$ & $61 \mathrm{ab}$ & $68 a$ & 3.456 \\
\hline
\end{tabular}

(a and b) Means within a row with different letters differ $(P<0.05)$.

a Treatments: SO, sunflower oil and HPO, hydrogenated palm oil.

b S.E.M.: standard error of least square means.

c Energy-corrected milk $=$ milk $(\mathrm{kg}) \times(0.071 \times$ fat $(\%)+0.043 \times$ protein (\%) + 0.2224) (Bocquier et al., 1993).

vs. 0.696), and tended to increase that of DM $(P=0.06)$ and $\mathrm{CP}(P=0.07)$, but no significant differences in apparent digestibility of EE, NDF or ADF were observed (contrast 1: control vs. SO and HPO). Supplementation with HPO or SO did not result in significant differences in the apparent digestibility of DM, OM, CP, EE, NDF and ADF (contrast 2: SO vs. HPO).

\subsection{Milk yield and composition}

The effects of the diets on milk yield and composition are presented in Table 4. Milk yield and energy-corrected milk were higher $(P<0.05)$ for ewes fed HPO relative to those fed control diet. Contents $(\mathrm{g} / \mathrm{kg})$ of fat and protein were not affected by treatments, however, yield ( $\mathrm{g} /$ day) of fat and protein were higher $(P<0.05)$ for ewes fed HPO diet.

\subsection{Fatty acid composition of milk}

Table 5 shows the fatty acid composition of milk fat from ewes fed control and lipid supplemented rations. Supplementation with vegetable fats did not affect short and medium chain fatty acid (C4:0-C14:0, and some C16:0) composition (Table 5).

Supplementation with HPO increased C14:1, C16:1 and $\mathrm{C} 16: 0$ content and reduced $\mathrm{C} 18: 0$ and $\mathrm{C} 18: 1$ cis- 9 content in milk fat.

Feeding $12 \mathrm{~g} / \mathrm{kg}$ SO, characterized by greater unsaturated fatty acids content (Table 2 ), significantly increased this fatty acids class in milk. The concentration of cis-9 trans-11 CLA and VA in milk fat were higher for ewes fed the So diet. Milk fat from diets with SO had $36 \%$ more VA and $29 \%$ more cis-9 trans-11 CLA than milk fat from the control diet, while supplementation with HPO produced milk fat with $15 \%$ more cis -9 trans-11 CLA.

\section{Discussion}

Digestibility of nutrients in ruminant rations with added fat is variable, depending on the quantity and type of fat used (Doreau and Chilliard, 1997). Hogan et al. (1972) observed the highest DM and OM digestibility values in 
Table 5

Fatty acid composition ( $\mathrm{g} / 100 \mathrm{~g}$ of total fatty acids) of milk fat from ewes fed diets supplemented with vegetable fats (data are least squares means \pm S.E.).

\begin{tabular}{|c|c|c|c|c|}
\hline & \multicolumn{3}{|c|}{ Treatment $^{\mathrm{a}}$} & \multirow[t]{2}{*}{ S.E.M.' } \\
\hline & Control & SO & HPO & \\
\hline $\mathrm{C} 6: 0$ & 1.76 & 1.83 & 1.72 & 0.052 \\
\hline C8:0 & 1.68 & 1.76 & 1.72 & 0.065 \\
\hline C10:0 & 5.25 & 5.52 & 5.55 & 0.236 \\
\hline C11:0 & 0.21 & 0.22 & 0.24 & 0.011 \\
\hline $\mathrm{C} 12: 0$ & 3.44 & 3.63 & 3.75 & 0.157 \\
\hline C14:0 & 7.76 & 8.01 & 8.20 & 0.219 \\
\hline $\mathrm{C} 14: 1$ & $0.26 \mathrm{~b}$ & $0.27 \mathrm{ab}$ & $0.29 a$ & 0.010 \\
\hline C15:0 & 0.76 & 0.75 & 0.82 & 0.025 \\
\hline C15:1 & 0.31 & 0.32 & 0.33 & 0.012 \\
\hline $\mathrm{C} 16: 0$ & $35.39 b$ & $34.96 b$ & $36.84 a$ & 0.449 \\
\hline $\mathrm{C} 16: 1$ & $1.05 \mathrm{~b}$ & $1.11 \mathrm{~b}$ & $1.28 \mathrm{a}$ & 0.069 \\
\hline $\mathrm{C} 17: 0$ & 0.28 & 0.29 & 0.30 & 0.019 \\
\hline $\mathrm{C} 17: 1$ & $0.19 a b$ & $0.18 \mathrm{~b}$ & $0.20 \mathrm{a}$ & 0.007 \\
\hline C18:0 & $15.62 \mathrm{a}$ & $14.97 \mathrm{a}$ & $13.14 \mathrm{~b}$ & 0.470 \\
\hline C18:1 trans-11 (vaccenic acid) & $0.88 \mathrm{~b}$ & $1.20 \mathrm{a}$ & $0.92 b$ & 0.060 \\
\hline C18: 1 cis -9 & $17.63 \mathrm{ab}$ & $17.76 a$ & $16.68 b$ & 0.362 \\
\hline C $18: 1$ cis -11 & 0.45 & 0.46 & 0.43 & 0.021 \\
\hline C18:2 cis-9, cis- 12 & $2.71 \mathrm{~b}$ & $3.04 a$ & $2.92 \mathrm{ab}$ & 0.111 \\
\hline C18:2 cis-9 trans- 11 CLA & $0.55 c$ & $0.71 \mathrm{a}$ & $0.63 \mathrm{~b}$ & 0.019 \\
\hline C18: 2 trans -10, cis -12 CLA & 0.096 & 0.092 & 0.086 & 0.005 \\
\hline C18:3 & $0.32 \mathrm{~b}$ & $0.42 \mathrm{a}$ & $0.43 a$ & 0.015 \\
\hline $\mathrm{C} 20: 0$ & 0.16 & 0.16 & 0.16 & 0.009 \\
\hline $\mathrm{C} 22: 0$ & $0.069 \mathrm{a}$ & $0.067 \mathrm{a}$ & $0.056 \mathrm{~b}$ & 0.004 \\
\hline C24:0 & 0.05 & 0.05 & 0.05 & 0.005 \\
\hline Unsaturated & $24.29 \mathrm{~b}$ & $25.46 \mathrm{a}$ & $24.18 \mathrm{~b}$ & 0.440 \\
\hline Polyunsaturated & $3.66 b$ & $4.23 a$ & $4.06 a$ & 0.129 \\
\hline Monounsaturated & $20.64 a b$ & $21.22 \mathrm{a}$ & $20.12 b$ & 0.384 \\
\hline Saturated & 73.24 & 72.72 & 72.85 & 0.460 \\
\hline \multicolumn{5}{|l|}{ Desaturase index ${ }^{\mathrm{C}}$} \\
\hline $\mathrm{C} 14: 1: \mathrm{C} 14: 0$ & $0.034 b$ & $0.034 a b$ & $0.036 \mathrm{a}$ & 0.0008 \\
\hline $\mathrm{C} 16: 1: \mathrm{C} 16: 0$ & $0.031 \mathrm{~b}$ & $0.032 \mathrm{ab}$ & $0.035 a$ & 0.0017 \\
\hline C18: 1 cis-9:C18:0 & $1.13 b$ & $1.22 \mathrm{ab}$ & $1.30 \mathrm{a}$ & 0.040 \\
\hline C18: 2 cis- 9 trans $-11: C 18: 1$ trans -11 & $0.71 \mathrm{~b}$ & $0.70 \mathrm{~b}$ & $0.84 a$ & 0.051 \\
\hline Index of atherogenicity ${ }^{d}$ & $2.94 \mathrm{ab}$ & $2.81 \mathrm{~b}$ & $3.10 \mathrm{a}$ & 0.090 \\
\hline
\end{tabular}

$(\mathrm{a}-\mathrm{c})$ Means within a row with different letters differ $(P<0.05)$.

a Treatments: SO, sunflower oil and HPO, hydrogenated palm oil.

b S.E.M.: standard error of least square means.

c Ratio of $\Delta^{9}$-desaturase products to their precursor fatty acids in milk fat.

d (C12:0 $+4 \times C 14: 0+C 16: 0) /$ sum of unsaturated fatty acids (from Ulbright and Southgate, 1991).

Merino sheep consuming alfalfa hay supplemented with SO (OM digestibility $=66 \%$ in diets without oil vs. $71.6 \%$ in diets supplemented with SO). However, neither Reddy et al. (2003), in sheep given a calcium soap of palm oil supplement, nor Wachira et al. (2000), in sheep fed different sources of fat, observed differences in DM or OM digestibility.

Other authors have also reported high CP digestibility values, concurring with those observed in our study. Appeddu et al. (2004) reported higher CP digestibility values in lactating ewes given a ration supplemented with calcium soaps of palm oil and tallow than in those fed rations that did not include a fat supplement.

Inclusion of non-protected lipids in ruminant rations is generally associated with negative effects on ruminal digestion, particularly on structural carbohydrate digestibility. Nevertheless, in addition to ourselves, other authors (Ohajuruka et al., 1991; Salado et al., 2004) observed no differences in NDF and ADF digestibility using fat supplements, either. Likewise, Zervas et al. (1998) did not observe significant differences in NDF and ADF digestibility in dairy ewes fed $400 \mathrm{~g}$ of grass hay and $600 \mathrm{~g}$ of concentrate with a $5 \%$ soy oil content. Ohajuruka et al. (1991) report that it is possible to include up to $5 \%$ fat in rations with $60 \%$ forage without adverse effects on digestion. In the present study, the amount of forage (60\%) and the levels of oil used (1.2\% on a dry matter basis) may have minimized the effects of the fat on fibre digestion.

Although supplementation with moderate amounts of fat is usually associated with increased apparent digestibility of lipids (Eastridge and Firkins, 2000; Reddy et al., 2003), other studies report results similar to our own. Palmquist (1991) using different fat supplements did not observe differences in apparent digestibility of fatty acids. Using fat supplements with different degrees of saturation, Harvatine and Allen (2006) observed no differences in apparent digestibility of fatty acids either, although these authors did observe a linear decrease in apparent digestibility of the fatty acids as the level of saturation of the fat supplement increased. Doreau and Chilliard (1997) indicated that apparent digestibility of fat measured for the whole digestive tract is questionable and should be used 
only to compare the digestibility of different sources of lipids given in the same amounts.

Despite the fact that the 3 diets supplied the same amount of net energy for lactation, the HPO supplement increased milk yield and ECM. This indicates that the nonfermentable energy in the form of saturated fat supplied by the HPO diet was more efficiently used for milk production than that of the other diets. Salado et al. (2004) obtained similar results in dairy cattle when a ration supplemented with a partially hydrogenated vegetable oil was compared with an isoenergetic diet without added fat. In that study, milk yield increased in cows supplemented with hydrogenated fat but no increase in total energy intake was detected. Furthermore, animals fed the HPO supplement did not display greater weight loss or a higher level of plasma non-esterified fatty acids than those given the isoenergetic diet without added fat. These authors conclude that further investigation of the mechanisms that increase milk production is needed.

Wu et al. (1993) compared a control ration, without added fat, to rations containing $2.5 \%$ saturated fat of different kinds in dairy cattle. These authors did not observe differences in DM intake, but did report greater milk production with the hydrogenated fat supplement.

Despite their differences in fatty acid profile, supplementation with HPO or SO did not result in significant differences in the percentage of milk fat and protein in the present study (Table 4). Our results concur with those of Wu et al. (1993) and Bu et al. (2007) in cows. Other studies, using saturated or protected fats (Grummer, 1991; Palmquist and Beaulieu, 1993, in cows; Pérez Alba et al., 1997; Gargouri et al., 2006, in sheep), report an increase in the percentage of milk fat. Results of dietary supplementation with unprotected oils rich in PUFA are quite varied. Using rapeseed oil, Mir et al. (1999) obtained a significant increase in both the percentage and amount of milk fat in dairy goats. On the other hand, neither Kitessa et al. (2001), with fish oil in goats, nor Allred et al. (2006), with fish and soy oils in cows, observed significant differences. Finally, studying the effects of different types of vegetable oils used as supplements, Zheng et al. (2005) and Bell et al. (2006), in cows, and Zervas et al. (1998) and Zhang et al. (2006), in dairy ewes, observed that vegetable oils sharply decreased the percentage of milk fat.

Previous studies indicated that diets with a vegetable oil supplement must induce changes in ruminal fermentation in order to cause a significant reduction in fat synthesis (Griinari et al., 1998). Kalscheur et al. (1997) have also observed that vegetable oil-supplemented diets that maintain a normal ruminal environment have minimal effect on milk fat synthesis. Our study used a moderate $(1.2 \%$ on a dry matter basis) level of SO, which probably did not upset the ruminal environment, as indicated by the absence of any effect on NDF or ADF digestibility values in Experiment 1 (Table 3).

Huang et al. (2008), when supplementing diets with $5 \%$ soy oil; Bell et al. (2006), when supplementing diets with $6 \%$ safflower oil, in dairy cattle; and Casals et al. (2006), when supplementing diets with $2.7 \%$ linseed, in dairy ewes, also failed to observe treatment effects on milk protein content. In contrast, other authors reported that milk protein decreases with fat supplementation (Wu et al., 1993, in cows; Pérez Alba et al., 1997; Casals et al., 1999, in ewes). The higher fat and protein daily yields (g/day) observed in the milk of HPO diet animals was a result of the greater milk yield registered in this group (Table 4).

\subsection{Fatty acid composition of milk}

Reduction in short and medium chain fatty acid content in milk after dietary supplementation using oils with a high long-chain fatty acid content has been reported in numerous studies in cattle (Allred et al., 2006; Bell et al., 2006), sheep (Zhang et al., 2006; Chiofalo et al., 2004) and goats (Schmidely and Sauvant, 2001).

Short and medium chain fatty acids are synthesized from acetate and $\beta$-hydroxybutyrate in the mammary gland (Chilliard et al., 2000). The decrease in the percentage of these fatty acids in milk when fats are added to the ration is attributed to the fact that long-chain fatty acids (18 or more carbon atoms), from the feed or the mobilization of body reserves, inhibit synthesis of acetyl-CoA carboxylase, thus decreasing de novo synthesis in mammary gland cells (Palmquist and Beaulieu, 1993). Fat from the feed also has an indirect effect on lipogenesis in the mammary gland, as it modifies ruminal fermentation, decreasing availability of acetate and $\beta$-hydroxybutyrate, both of which are precursors of mammary lipogenesis (Schmidely and Sauvant, 2001). Nevertheless, this decrease only occurs when the fat added to the ration affect ruminal functioning (Chilliard et al., 2000).

As can be deduced from Experiment 1 (Table 3), the levels of added fat in our study did not produce negative effects on ruminal digestion, which may explain the absence of any response to the dietary supplements.

In goats, Sanz Sampelayo et al. (2002) did not observe changes in the concentration of short and medium chain (up to $14^{\circ} \mathrm{C}$ ) fatty acids after adding fats to the diet, either.

The hydrogenated palm oil (HPO) diet contained higher levels of $\mathrm{C} 16: 0$ and $\mathrm{C} 16: 1$ than control and sunflower oil (SO) diets, and greater concentrations of C14:1 than those of the control diet (Table 5), as a result of the greater C14:0 and $C 16: 0$ content of the HPO diet. Both C14:0 and C16:0 are precursor of $C 14: 1$ and $C 16: 1$ due to $\Delta^{9}$-desaturase activity in the mammary gland (Chilliard et al., 2000). These results concur with those obtained in dairy ewes by Appeddu et al. (2004) and Casals et al. (2006) with calcium soaps of palm oil.

The greater concentration of c18:0 observed in the milk of ewes fed the control and So diets compared with that of ewes given the HPO diet may be due to the total ruminal biohydrogenation of part of the unsaturated dietary C18. Grummer (1991) indicates that it is easier to increase the C18:0 content of the fat in milk with supplements rich in mono and polyunsaturated fatty acids than with supplements that provide stearic acid per se. The higher levels of oleic acid (cis-9 c18:1) observed in the milk of ewes given the SO diet compared with those in the milk of ewes given the HPO diet may be partly due to the action of $\Delta^{9}$ desaturase enzyme in the mammary gland (Griinari et al., 2000 ) over a portion of the $C 18: 0$ generated in the rumen, 
and partly to the fact that SO contains higher concentrations of oleic acid than HPO (Table 2).

The increase in milk cis-9 trans-11 CLA and VA concentration with the SO was expected. cis-9 trans-11 CLA and VA are intermediates of the biohydrogenation of $\mathrm{C} 18: 2$ cis- 9 cis-12 (linoleic acid), which is present in high concentrations in sunflower oil. Several authors indicated that the main proportion of CLA (from 64 to $98 \%$ ) in milk fat is produced in the mammary gland by $\Delta^{9}$-desaturase from VA (Griinari et al., 2000). The cis-9 trans-11 CLA content of milk fat in the So diets came in part from ruminal biohydrogenation of linoleic acid and in part was produced by $\Delta^{9}$-desaturase activity, from C18:1 trans-11, while the cis9 trans-11 CLA of milk fat in the HPO diets came almost entirely from desaturation of VA in the mammary gland, due to $\Delta^{9}$-desaturase activity.

There are other studies that note an increase in VA and cis-9 trans-11 CLA content in milk fat after supplementing diets with oils rich in PUFA. These studies include those of Zhang et al. (2006), in ewes fed linseed and sunflower oils, Bernard et al. (2005), in goats consuming linseed and sunflower oils and Bouattour et al. (2008), in goats consuming soybean oil. On the other hand, as mentioned earlier, studies with hydrogenated palm oil are scarce. The few studies carried out with calcium soaps of palm oil report an increase (Allred et al., 2006, in dairy cows) or no effect (Casals et al., 2006, in dairy ewes) in C18:2 cis-9 trans-11 CLA milk fat content.

The product:precursor ratios has been used as a possible indicator of $\Delta^{9}$-desaturase activity (Perfield et al., 2002; Lock and Garnsworthy, 2003; Allred et al., 2006; Soyeurt et al., 2008). There are four main products of $\Delta^{9}$ desaturase activity in the mammary gland of ruminants, $\mathrm{C} 14: 1, \mathrm{C} 16: 1, \mathrm{C} 18: 1$ cis-9 and $\mathrm{C} 18: 2$ cis-9 trans-11, which are produced from $\mathrm{C} 14: 0, \mathrm{C16}: 0, \mathrm{C} 18: 0$ and $\mathrm{C} 18: 1$ trans-11, respectively. Of these, the best indicator of $\Delta^{9}$-desaturase activity is the $\mathrm{C} 14: 1: \mathrm{C} 14: 0$ ratio because all of the $\mathrm{C} 14: 0$ in milk fat is produced via de novo synthesis in the mammary gland, consequently desaturation is the only source of C14:1 (Corl et al., 2000). The HPO supplemented diet displayed a greater $\mathrm{C} 14: 1: \mathrm{C} 14: 0, \mathrm{C} 16: 1: \mathrm{C} 16: 0, \mathrm{C} 18: 1$ cis9:C18:0 and $C 18: 2$ cis- 9 trans-11:C18:1 trans- 11 ratios than control diets (Table 5). The higher C18:2 cis-9 trans-11 CLA values of milk from the HPO ewes compared with that of control animals may be partially attributed to greater $\Delta^{9}$-desaturase activity in the mammary glands of the former ewes. The high levels of cis-9 trans-11 CLA in the milk of ewes given SO but that showed no increase in $\Delta^{9}$-desaturase activity suggests that the sources of cis-9 trans-11 CLA in this milk were ruminal biohydrogenation and desaturation of VA in the mammary gland. The high levels of $\Delta^{9}$-desaturase activity observed in diets with palm oil (HPO) have also been reported for dairy cows by Allred et al. (2006) in diets with calcium soaps of palm oil. Factors affecting the activity of $\Delta^{9}$-desaturase are not well understood, but may be influenced by genetics, stage of lactation and nutrition (Lock and Garnsworthy, 2003). The review by Ntambi (1999) reports that diets rich in saturated fatty acids induced desaturase activity in rat liver and diets rich in PUFA such as linoleic acid, diminished $\Delta^{9}$-desaturase activity.
As a result of the high mono- and poly-unsaturated fatty acid content of SO diets, the atherogenic index of milk fat from SO treatment (Table 5) was low. The importance of this index is currently under discussion, but seems to be relevant in the case of people consuming an excess of saturated fat.

\section{Conclusions}

Supplementation of diet with $12 \mathrm{~g} / \mathrm{kg}$ sunflower or hydrogenated palm oil did not affect the NDF or ADF digestibility of the rations. Inclusion of $12 \mathrm{~g} / \mathrm{kg}$ HPO in the diet increased milk production without affecting the percentages of fat and protein. Adding $12 \mathrm{~g} / \mathrm{kg}$ HPO or SO to the concentrate increased CLA concentration in milk fat. Nevertheless, supplementation with SO was more effective than $\mathrm{HPO}$ in increasing CLA concentration in milk fat. Feeding SO could be a valuable tool for farmers to dairy sheep under intensive feeding system to produce milk and dairy products enriched in PUFA, CLA, and VA, which are considered healthier for human consumers.

\section{Acknowledgements}

The authors acknowledge the collaboration of Mr. G. Rodriguez López for animal care and sample collection. This research was funded by the Complutense University of Madrid (Project PR3/04-12381).

\section{References}

Allred, S.L., Dhiman, T.R., Brennand, C.P., Khanal, D.J., Luchini, N.D., 2006. Milk and cheese from cows fed calcium salts of palm and fish oil alone or in combination with soybean products. J. Dairy Sci. 89, 234-248.

AOAC, 1999. Official Methods of Analysis, 16th ed. Assoc. Off. Anal. Chem., Arlington, VA.

Appeddu, L.A., Ely, A.D.G., Aaron, D.K., Deweese, W.P., Fink, E., 2004. Effects of supplementating with calcium salts of palm oil fatty acids or hydrogenated tallow on ewe milk production and twin lamb growth. J. Anim. Sci. 82, 2708-2789.

Bell, J.A., Griinari, J.M., Kennelly, J.J., 2006. Effects of safflower oil, flaxseed oil, monensin, and viamin e on concentration of conjugated linoleic acid in bovine milk fat. J. Dairy Sci. 89, 733-748.

Bernard, L., Rouel, L., Leroux, C., Ferlay, A., Faulconier, Y., Legrand, P., Chilliard, Y., 2005. Mammary lipid metabolism and milk fatty acid secretion in Alpine goats fed vegetable lipids. J. Dairy Sci. 88, 1478-1489.

Bocquier, F., Barillet, F., Guillouet, P., Jacquin, M., 1993. Prévision de l'énergie du lait de brebis à partir de différents résultats d'analyses: proposition de lait standard pour les brebis laitières. Ann. Zootech. 42, 57-66.

Bouattour, M.A., Casals, R., Albanell, E., Caja, G., 2006. Milk fatty acid composition and dairy performances in Lacaune sheep fed whole linseed and linseed oil with reference to CLA. J. Dairy Sci. 89 (Suppl. 1), 64

Bouattour, M.A., Casals, R., Albanell, E., Such, X., Caja, G., 2008. Feeding soybean oil to dairy goats increases conjugated linoleic acid in milk. J. Dairy Sci. 91, 2399-2407.

Bu, D.P., Wang, J.Q., Dhiman, T.R., Liu, S.J., 2007. Effectiveness of oils rich in Linoleic and Linolenic acids to enhance conjugated linoleic acid in milk from dairy cows. J. Dairy Sci. 90, 998-1007.

Casals, R., Caja, G., Such, X., Torre, C., Calsamiglia, S., 1999. Effects of calcium soaps and rumen undegradable protein on the milk production and composition of dairy ewes. J. Dairy Res. 66, 177-191.

Casals, R., Caja, G., Pol, M.V., Such, X., Albanell, E., Gargouri, A., Casellas, J., 2006. Response of lactating dairy ewes to various levels of dietary calcium soaps of fatty acids. Anim. Feed Sci. Technol. 131, 312-332.

Chilliard, Y., Ferlay, A., Mansbridge, R.M., Doreau, M., 2000. Ruminant milk fat plasticity: nutritional control of saturated, polyunsaturated, trans and conjugated fatty acids. Ann. Zootech. 49, 181-205.

Chiofalo, B., Liotta, L., Zumbo, A., Chiofalo, V., 2004. Administration of olive cake for ewe feeding: effect on milk yield and composition. Small Rumin. Res. 55, 169-176. 
Corl, B.A., Baumgard, L.H., Bauman, D.E., Griinari, J.M., 2000. Role of $\Delta^{9}$ desaturase in the synthesis of the anticarcinogenic isomer of conjugated linoleic acid and other milk fatty acids. In: Proceedings of the Cornell Nutrition Conference. Cornell University, Rochester, NY, pp. 203-212.

Doreau, M., Chilliard, Y., 1997. Digestion and metabolism of dietary fat in farm animals. Br. J. Nutr. 78 (Suppl. 1), 15-35.

Eastridge, M.L., Firkins, L.L., 2000. Feeding tallow triglycerides of different saturation and particle size to lactating dairy cows. Anim. Feed Sci. Technol. 83, 249-259.

Gargouri, A., Caja, G., Casals, R., Mezghani, I., 2006. Lactational evaluation of effects of calcium soap of fatty acids on dairy ewes. Small Rumin. Res. 66, 1-10.

Griinari, J.M., Dwyer, D.A., McGuire, M.A., Bauman, D.E., Palmquist, D.L., Nurmela, K.V.V., 1998. Trans-octadecanoic acids and milk fat depression in lactating cows. J. Dairy Sci. 81, 1251-1261.

Griinari, J.M., Corl, B.A., Lacy, S.H., Chouinard, P.Y., Nurmela, K.V.V., Bauman, D.E., 2000. Conjugated linoleic acid is synthesized endogenously in lactating cows by $\Delta^{9}$ desaturase. J. Nutr. 130, 2285-2291.

Grummer, R., 1991. Effect of feed on the composition of milk fat. J. Dairy Sci. 74, 3244-3257.

Harvatine, K.J., Allen, M.S., 2006. Effects of fatty acid supplements on milk yield and energy balance of lactating dairy cows. J. Dairy Sci. 89, 1081-1091.

Hogan, J.P., Connell, P.J., Mills, S.C., 1972. The digestion of safflower oilcasein particles protected against ruminal hydrogenation in sheep. Aust. J. Agric. Res. 23, 87-95.

Huang, Y., Schoonmaker, J.P., Bradford, B.J., Beitz, D.C., 2008. Response of milk fatty acid composition to dietary supplementation of soy oil, conjugated linoleic acid, or both. J. Dairy Sci. 91, 260-270.

INRA, 2007. Alimentation des bovins, ovins el caprins. Besoins des animaux-valeurs des aliments. Éditions Quae, versalles Cedex.

Ip, C., Banni, S., Angioni, E., Carta, G., McGinley, J., Thompson, H.J., Barbano, D., Bauman, D., 1999. Conjugated linoleic acid-enriched butter fat alters mammary gland morphogenesis and reduces cancer risk in rats. J. Nutr. $129,2135-2142$.

Kalscheur, K.F., Teter, B.B., Piperova, L.S., Erdman, R.A., 1997. Effect of fat source of duodenal flow of trans-C18:1 fatty acids and milk fat production in dairy cows. J. Dairy Sci. 80, 2115-2126.

Kitessa, S.M., Gulati, S.K., Ashes, J.R., Fleck, E., Scott, T.W., Nichols, P.D., 2001. Utilisation of fish oil in ruminants II transfer of fish oil acids into goats' milk. Anim. Feed Sci. Technol. 89, 201-208.

Lock, A.L., Garnsworthy, P.C., 2003. Seasonal variation in milk conjugated linoleic acid and $\Delta^{9}$-desaturase activity in dairy cows. Livestock Prod. Sci. 79, 47-59.

Lock, A.L., Teles, B.M., Perfield, J.W., Bauman, D.E., Sinclair, L.A., 2006. A conjugated linoleic acid supplement containing trans-10, cis-12 reduces milk fat synthesis in lactating sheep. J. Dairy Sci. 89, 1525-1532.

Mir, Z., Goonewardene, L.A., Okine, E., Jaegar, S., Scheer, H.D., 1999. Effects of feeding canola oil on constituents, conjugated linoleic acid (CLA) and long chain fatty acids in goat milk. Small Rumin. Res. 33, 137-142.

Ntambi, J.M., 1999. Regularion of stearoyl-CoA desaturase by polyunsaturated fatty acids and cholesterol. J. Lipid Res. 40, 1549-1558.

Ohajuruka, O.A., Wu, Z., Palmquist, D.L., 1991. Ruminal metabolism, fiber, and protein digestion by lactating cows fed calcium soap or animalvegetable fat. J. Dairy Sci. 74, 2601-2609.

Palmquist, D.L., 1991. Influence of source and amount of dietary fat on digestibility in lactating cows. J. Dairy Sci. 74, 1354-1360.
Palmquist, D.L., Beaulieu, A.D., 1993. Feed and animal factors influencing milk fat composition. J. Dairy Sci. 76, 1753-1771.

Park, Y., Storkson, J.M., Albright, K.J., Liu, W., Pariza, M.W., 1999. Evidence the trans-10, cis-12 isomer of conjugated linoleic acid induces body composition changes in mice. Lipids 34, 235-241.

Pérez Alba, L., De Souza Cavalcanti, M.S., Perez Hernández, M., Martinez Marîn, A., Fernảndez Marîn, G., 1997. Calcium soaps of olive fatty acids in the diets of Manchega dairy ewes: effects on digestibility and production. J. Dairy Sci. 80, 3316-3324.

Perfield, J.W., Bernal-Santos, G., Overton, T.R., Bauman, D.E., 2002. Effects of dietary supplementation of rumen-protected conjugated linoleic acid in dairy cows during established lactation. J. Dairy Sci. 85, 2609-2617.

Peterson, D.G., Baumgard, L.H., Bauman, D.E., 2002. Short communication: milk fat response to low doses of trans-10, cis-12 conjugated linoleic acid (CLA). J. Dairy Sci. 85, 1764-1766.

Reddy, Y., Krishna, R.N., Rao, E.R., Reddy, T.J., 2003. Influence of dietary protected lipids on intake and digestibility of straw based diets in Deccani sheep. Anim. Feed Sci. Technol. 106, 29-38.

Salado, E.E., Gagliostro, G.A., Becu-Villalobos, D., Lacau-Mengido, I., 2004. Partial replacement of corn grain by hydrogenated oil in grazing dairy cows in early lactation. J. Dairy Sci. 87, 1265-1278.

Sanz Sampelayo, M.R., Pérez, L., Martín Alonso, J.J., Amigo, L., Boza, J., 2002. Effects of concentrates with different contents of protected fat rich in PUFAs on the performance lactating Granadina goats Part II. Milk production and composition. Small Rumin. Res. 43, 141-148.

Schmidely, P., Sauvant, D., 2001. Taux butyreux et la composition de la matière gras du lait chez les petits ruminants: effets de l'apport de matières grasses ou d'aliment concentré. INRA Prod. Anim. 14, 337-354.

Soyeurt, H., Dehareng, F., Mayeres, P., Bertozzi, C., Gengler, N., 2008. Variation of $\Delta^{9}$-desaturase activity in dairy cattle. J. Dairy Sci. 91 , 3211-3224.

Ulbright, T.L.V., Southgate, D.A.T., 1991. Coronary heart disease: seven dietary factors. Lancet 338, 985-992.

Van Soest, P.J., Robertson, J.B., Lewis, B.A., 1991. Methods for dietary fiber, neutral detergent fiber, and nonstarch polysaccharides in relation to animal nutrition. J. Dairy Sci. 74, 3583-3597.

Wachira, A.M., Sinclair, L.A., Wilkinson, R.G., Hallett, K., Enser, M., Wood, J.D., 2000. Rumen biohydrogenation of n-3 polyunsaturated fatty acids and their effects on microbial efficiency and nutrient digestibility in sheep. J. Agric. Sci. (Camb.). 135, 419-428.

Wolff, R.L., Fabien, 1989. Utilisation de l'isopropanol pour l'extraction de la matiere grasse de produits laitiers et pour l'esterification subsequente des cides gras. Le Lait 69, 33-46.

Wu, Z., Huber, J.T., Sleiman, F.T., Simas, J.M., Chen, K.H., Chan, S.C., Fontes, C. 1993. Effect of three supplemental fat sources on lactation and digestion in dairy cows. J. Dairy Sci. 76, 3562-3570.

Zervas, G., Fegeros, K., Koytsotolis, K., Goulas, C., Mantzios, A., 1998. Soy hulls as a replacement for maize in lactating dairy ewe diets with or without dietary fat supplements. Anim. Feed Sci. Technol. 76, 65-75.

Zhang, R., Mustafa, A.F., Zhao, X., 2006. Effects of flaxseed supplementation to lactating ewes on milk composition, cheese yield, and fatty acid composition of milk and cheese. Small Rumin. Res. 63, 233241.

Zheng, H.C., Liu, J.X., Yao, J.H., Yuan, O., Ye, H.W., Wu, M., 2005. Effects of dietary sources of vegetable oils on performance of high-yielding lactating cows and conjugated linoleic acids in milk. J. Dairy Sci. 88, 2037-2042. 